\title{
PENGEMBANGAN BAHAN AJAR BERBASIS \\ KONTEKSTUAL PADA MATAKULIAH BIOLOGI UMUM
}

\author{
Agil Lepiyanto \\ Dasrieny Pratiwi
}

Pendidikan Biologi FKIP Universitas Muhammadiyah Metro
E-mail: lepi22evolusi@ gmail.com, dasrienyp@ yahoo.com

\begin{abstract}
The aim of this research is to gain contextual teaching material in in general biology class. The type of this research is developmental research or Research and Development $(R \& D)$. Developmental model which is used in this research was adapted from Sugiyono and it was limited until the step of product's test. The result of this research shows that the quality of contextual teaching material in biology subject which is developed by the expert of teaching design, the media expert, the biology lecturer, and the students who take this subject have a valid category with the following ideality scores: 4.076, 4.09, 4.19, and 4.03. The product of contextual teaching material should be revised to gain a better result.
\end{abstract}

Kata Kunci: bahan ajar, kontekstual

Salah satu mata kuliah yang dapat mengembangkan potensi calon guru adalah mata kuliah biologi umum, mata kuliah ini dilaksanakan pada semester satu, sehingga bisa menjadi salah satu mata kuliah yang menjadi pondasi dan mendukung mata kuliah lain di Pendidikan Biologi. Biologi umum merupakan mata kuliah yang dalam pembelajaran terdapat praktikum, sehingga pembelajarannya tidak hanya teoritis tetapi juga melakukan kegiatan praktikum baik di laboratorium maupun praktikum lapangan di luar kampus. Hasil observasi bahan ajar yang digunakan hanya mengandalkan power point yang disiapkan oleh dosen. Pemberian tugas yang dilakukan juga masih sebatas tugas pembuatan makalah, sehingga tidak banyak mengembangkan kompetensi mahasiswa sebagai calon tenaga pendidik.

Dari masalah yang terdapat pada matakuliah biologi umum dapat diberikan solusi yaitu pengembangan bahan ajar berbasis kontekstual. Pembelajaran kontekstual merupakan pembelajaran yang berorientasi pada penciptaan semirip mungkin dengan situasi "dunia nyata". Melalui pembelajaran kontekstual dapat membantu guru mengaitkan antara materi yang diajarkan dengan situasi nyata, sehingga dapat membantu siswa untuk memahami materi pelajaran.

Trianto (2011) menjelaskan bahwa komisi pendidikan abad 21 merekomendaskan empat strategi yaitu learning to learn, learning to be, learning to do, learning to be together. Dari pendapat tersebut tentu saja pembelajaran berbasis kontekstual menjadi salah satu alternatif yang dapat dipilih untuk pendidikan abad 21 .

Trianto (2011) menjelaskan bahwa dengan menerapkan prinsip pembelajaran kontekstual diharapkan pembelajaran akan lebih bermakna bagi siswa, karena siswa akan bekerja secara ilmiah dan mengalami sendiri bukan hanya mentransfer pengathuan guru ke siswa. Bagaimana bentuk bahan ajar berbasis kontekstual pada perkuliahan Biologi umum. 
Komalasari (2013:6) menyatakan bahwa Pembelajaran kontekstual merupakan konsep belajar dan mengajar yang membantu guru mengaitkan antara materi yang diajarkannya dengan situasi dunia nyata siswa dan mendorong siswa membuat hubungan antara pengetahuan yang dimilikinya dengan penerapannya dalam kehidupan mereka sebagai anggota keluarga, warga negara dan pekerja.

Berdasarkan pendapat di atas dapat disimpulkan bahwa pembelajaran kontekstual membantu siswa menemukan ide-ide kreatif dalam proses pembelajaran melalui penemuan, penguatan dan keterhubungan dalam dunia nyata yang secara angsung dialami oleh siswa, siswa akan bekerja keras untuk mencapai tujuan pembelajarannya dengan menggunakan pengalaman dan pengetahuan sebelumnya untuk membangun pengetahuan baru selanjutnya siswa memanfaatkan kembali pemahaman dan kemampuannya dalam konteks di luar pembelajaran sehingga siswa akan mudah memahami dan mengingat apa yang dipelajarinya.

Menurut Rusman (2011:191) ciri khas CTL ditandai oleh tujuh komponen utama, yaitu 1) constructivism; 2) kontekstual; 3) questioning; 4) learning community; 5) modeling; 6) reflection; dan 7) authentic assessment.

\section{METODE}

Model penelitian dan pengembangan ini menggunakan model Research and Develompen (R\&D) yang dikembangkan oleh Prof Sugiyono pemilihan model R\&D dikarenakan prosedur dan langkah- langkah yang dilakukan sesuai dengan tujuan yang diharapkan dari penelitian pengembangan perangkat pembelajaran yang meliputi meneliti, mengembangkan, menguji dan memvalidasi produk pembelajaran berupa bahan ajar Biologi umum berbasis kontekstual.

Analisis bahan ajar dilakukan untuk melihat perangkat yang disusun telah memenuhi kriteria kevalidan, instrumen penilaian terdiri dari 5 derajat skala penilaian yaitu skala yang digunakan adalah lima, dimana angka (1) berarti sama sekali tidak baik, angka (2) berarti kurang baik, angka (3) berarti cukup baik, angka (4) berarti baik, dan angka (5) berarti sangat baik. Kristiana (2011:46) hasil data kevalidan perangkat pembelajaran dikonfersi ke data kuantitatif sehingga dapat dianalisis dengan menggunakan statistik deskriptif dengan prosedur sebagai berikut.

1. Merekap skor dari seluruh pertemuan.

2. Menghitung skor rata-rata untuk tiap aspek aktifitas.

3. Menghitung rata-rata keseluruhan.

4. Membuat kesimpulan tentang kepraktisan perangkat pembelajaran yang dikembangkan.

Kristiana (2011:46) kriteria kevalidan dari produk itu ditetapkan sebagai berikut.

1. Valid jika keseluruhan $\geq 3$

2. Cukup valid jika $2 \leq$ rata-rata keseluruhan $<3$

3. Tidak valid jika rata-rata keseluruhan $<2$

Langkah metode research and development $(\mathrm{R} \& \mathrm{D})$ dapat dilihat pada gambar 1. 


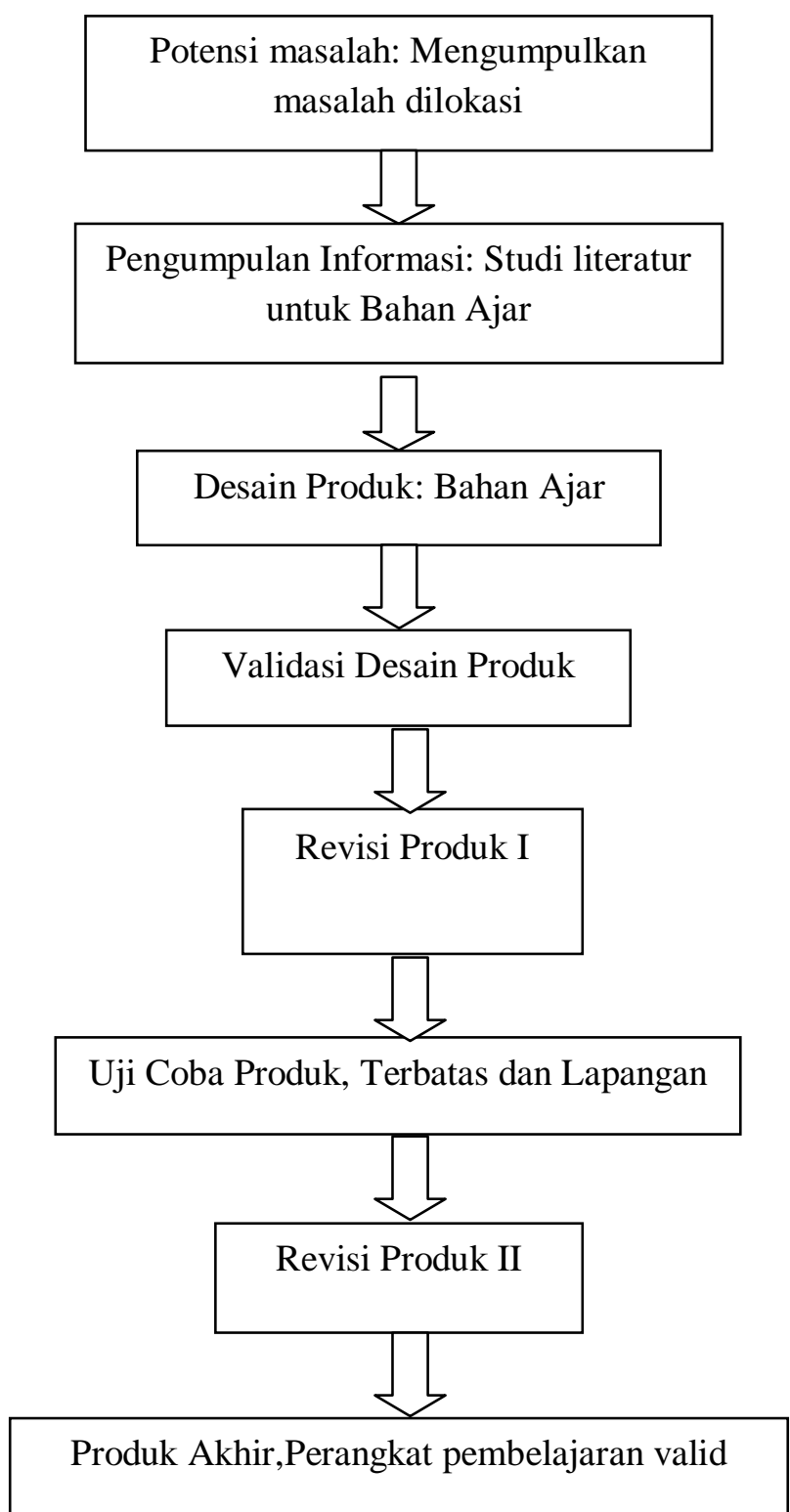

Gambar 1. Modifikasi research and development (R\&D) (Sugiyono:2011)

\section{HASIL}

Berikut ini merupakan hasil Data validasi bahan ajar oleh ahli dapat analisis data hasil penelitian. Hasil dilihat pada tabel 1. Data penilaian penelitian pengembangan bahan ajar Mahasiswa berupa penilaian bahan berbasis kontekstual berupa hasil ajar. dapat dilihat pada tabel 2 
Tabel 1. Hasil Analisis Validasi Ahli

\begin{tabular}{lcccc}
\hline \multicolumn{1}{c}{ Aspek } & \multicolumn{4}{c}{ Hasil Penilaian } \\
\cline { 2 - 5 } & Tahap 1 & Kriteria & Tahap 2 & Kriteria \\
\hline $\begin{array}{l}\text { Ahli Desain } \\
\text { Pembelajaran }\end{array}$ & 2.846 & Cukup Valid & 4.076 & Valid \\
\hline Ahli Isi Materi & 2.95 & Cukup Valid & 4.09 & Valid \\
\hline Dosen Pengampu & 3.30 & Valid & 4.19 & Valid \\
\hline
\end{tabular}

Tabel 2 Hasil Penilaian Mahasiswa

\begin{tabular}{ccc}
\hline \multirow{2}{*}{ Aspek } & \multicolumn{2}{c}{ Hasil Penilaian } \\
\cline { 2 - 3 } & Rata-rata & Kriteria \\
\hline Bahan Ajar & 4.03 & Valid \\
\hline
\end{tabular}

PEMBAHASAN

Pengembangan bahan ajar berbasis kontekstual diawali dengan melakukan analisis Potensi masalah. Hasil potensi masalah yang didapatkan pada perkuliahan Biologi umum di Universitas Muhammadiyah Metro adalah biologi umum merupakan mata kuliah yang dalam pembelajaran terdapat praktikum, sehingga pembelajarannya tidak hanya sekedar teoritis tetapi juga melakukan kegiatan praktikum baik di laboratorium maupun praktikum lapangan di luar kampus. Bahan ajar yang digunakan hanya mengandalkan power point yang disiapkan oleh dosen Pemberian tugas yang dilakukan juga masih sebatas tugas pembuatan makalah, sehingga tidak banyak mengembangkan kompetensi mahasiswa sebagai calon tenaga pendidik.

Tahap berikutnya dalam pengembangan bahan ajar adalah tahap mengumpulkan informasi. Tahapan ini merupakan kegiatan untuk mengumpulkan informasi yang dapat digunakan sebagai bahan untuk perencanaan bahan pembelajaran. Pengumpulan informasi dilakukan dengan cara studi referensi beberapa buku dan melakukan browsing internet. Hasil pengumpulan informasi difokuskan pada dua materi pokok yaitu BAB I berisi tentang Ekosistem dan Problem Lingkungan Hidup dan BAB II berisi materi Bioteknologi. Pemilihan materi ekosistem ini didasarkan adanya prototype hutan pembelajaran yang digagas oleh salah 
satu dosen di Universitas kriteria kevalidan menurut Muhammadiyah Metro yaitu Dr. Kristiana,maka didapatkan kriteria Muhfahroyin, S,Pd., M.TA. pemilihan cukup valid, sedangkan pada tahap 2 materi bioteknologi didasarkan dari didapatkan nilai 4,076. Hasil ini jika hasil analisis matakuliah yang ada di dikonversikan kedalam kriteria Pendidikan Biologi UM Metro belum kevalidan menurut Kristiana,maka ada matakuliah Bioteknologi. Bahan- didapatkan kriteria valid. Perbandingan bahan yang telah didapatkan kemudian nilai validasi bahan ajar menurut ahli dikembangkan menjadi desain produk desain pembelajaran dapat dilihat pada awal bahan ajar berbasis kontekstual. gambar 2. Menurut ahli isi materi, Tahap berikutnya setelah didapatkan bahan ajar yang dikembangkan draft bahan ajar adalah Validasi desain. didapatkan nilai 2,95. Hasil ini jika Tahapan ini merupakan kegiatan untuk dikonversikan kedalam kriteria menilai rasional rancangan produk kevalidan menurut Kristiana, maka yang dilakukan oleh para ahli, adapun didapatkan kriteria cukup valid, ahli yang menilai perangkat sedangkan pada tahap 2 didapatkan pembelajaran yang dikembangkan nilai 4,09. Hasil ini jika dikonversikan dapat dilihat pada tabel 3. Validasi ahli kedalam kriteria kevalidan menurut dilakukan melalui dua tahapan, hasil Kristiana, maka didapatkan kriteria analisis dari validasi ahli valid. Perbandingan nilai bahan ajar didapatkan,menurut ahli desain menurut isi materi dapat dilihat pada pembelajaran bahan ajar yang gambar 3

dikembangkan didapatkan nilai 2,84 .

Hasil ini jika dikonversikan kedalam

Tabel 3. Daftar validator Perangkat Pembelajaran

\begin{tabular}{ll}
\hline Ahli & Penilai \\
\hline Desain pembelajaran & Dr. Muhfahroyin, S.Pd., M.TA \\
\hline Isi Materi & Kartika Sari, M.B.T.s \\
\hline Dosen Pengampu & Dr. Agus Sujarwanta, M.Pd \\
& Suharno Zen, M.sc \\
\hline
\end{tabular}




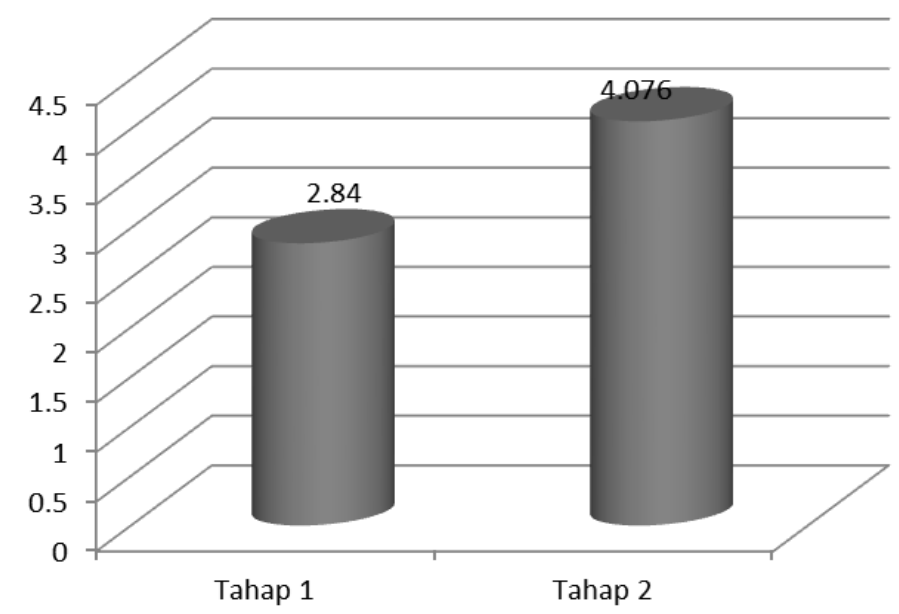

Gambar 2. Perbandingan nilai validasi bahan ajar menurut ahli desain pembelajaran

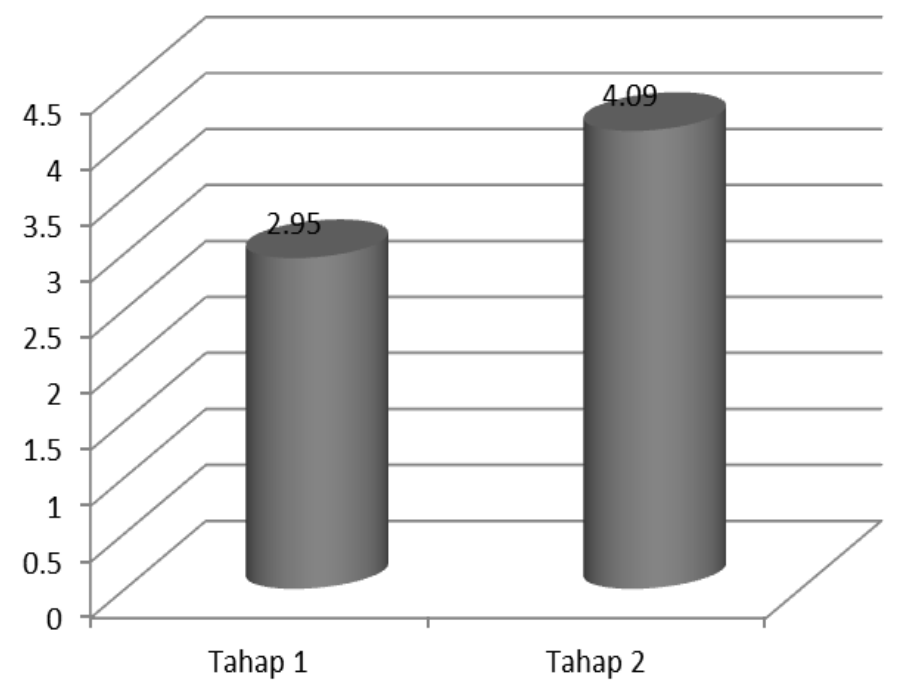

Gambar 3. Perbandingan nilai bahan ajar menurut isi materi

Menurut ahli dosen pengampu, maka didapatkan kriteria valid. bahan ajar yang dikembangkan Perbandingan nilai bahan ajar menurut didapatkan nilai 3.30. Hasil ini jika dosen pengampu dapat dilihat pada dikonversikan kedalam kriteria gambar 4. Hasil dari validasi kemudian kevalidan menurut Kristiana, maka dilakukan tahapan perbaikan desain. didapatkan kriteria valid, sedangkan Tahapan ini dilakukan untuk pada tahap 2 didapatkan nilai 4,19. memperbaiki kelemahan desain hasil Hasil ini jika dikonversikan kedalam validasi dan diskusi dengan para ahli. kriteria kevalidan menurut Kristiana, Berikut ini merupakan beberapa 
rekomendasi perbaikan dari validasi tahap 1 dapat dilihat pada tabel 4 .

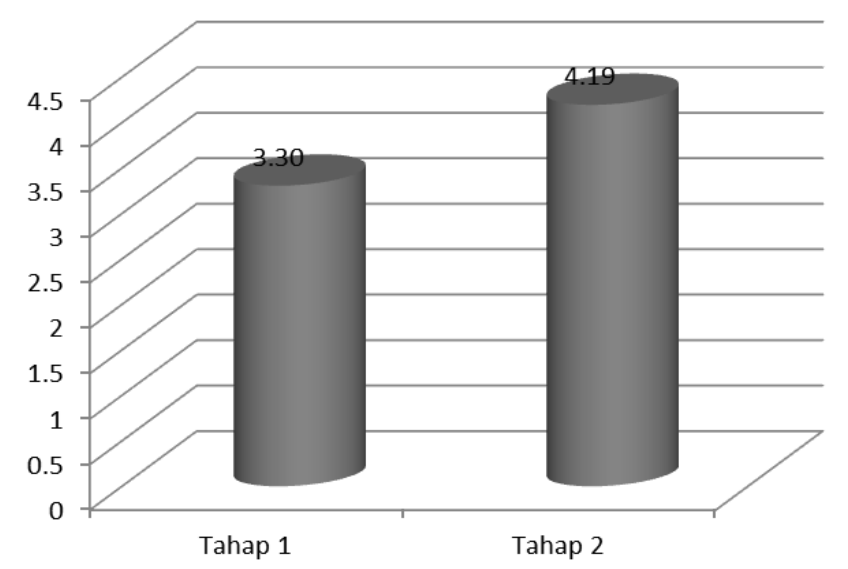

Gambar 4. Perbandingan nilai bahan ajar menurut Dosen Pengampu

Tabel 4. Rekomendasi perbaikan dari validasi tahap 1

\begin{tabular}{lll}
\hline Ahli & Rekomendasi \\
\hline Desain & 1. & bahan ajar belum lengkap komponennya, \\
Pembelaja & 2. Materi bioteknologi belum kontekstual \\
ran & 3. Cover belum menarik, layout diperbaiki dan rangkuman \\
& pada materi ekosistem belum ada \\
\hline Ahli & 1. & Rangkuman pada bab I Ekosistem dan Problem \\
Materi & & Lingkungan Hidup dengan materi pembelajaran belum \\
& ada \\
& 2. Kesesuaian rangkuman pada BAB II Bioteknologi \\
& 3engan materi pembelajaran belum sesuai \\
& 3. Lembar kegiatan mahasiswa pada bagian BAB II \\
& & Bioteknologi belum ada \\
\hline Dosen & 1. Tampilan fisik Bahan Ajar Biologi Umum. \\
Pengampu & 2. Gambar ada yang tidak diberi keterangan \\
& 3. Keterangan gambar ada yang salah \\
& 4. Tata letak gambar belum baik \\
& 5. & rangkuman tidak lengkap \\
& 6. Latihan mahasiwa belum lengkap
\end{tabular}

Tahapan berikutnya adalah uji coba produk. Tahap ini merupakan tahap penilaian mahasiswa terhadap bahan ajar yang dikembangkan. Tahapan ini dilakukan setelah bahan ajar divalidasi melalui 2 tahapan oleh ahli. Hasil penilaian mahasiswa didapatkan nilai
4.03, hasil ini jika dikonversikan kedalam kriteria kevalidan menurut Kristiana, maka didapatkan kriteria valid. Uji coba perangkat pembelajaran berbasis kontekstual seharusnya dilakukan dengan melakukan aplikasi ke kelas, namun tahapan ini baru akan 
dilakukan pada penelitian lanjutan dari penelitian ini.

\section{KESIMPULAN DAN SARAN}

\section{Kesimpulan}

Hasil Pengembangan bahan ajar sudah sesuai dengan pembelajaran kontekstual, hasil didasarkan penilain oleh ahli desain pembelajaran didapatkan nilai 4,076, sedangkan menurut ahli materi didapatkan 4,09, menurut dosen pengampu didapatkan 4,19 dan menurut penilaian mahasiswa didapatkan 4.03. Hasil ini jika dikonversikan pada kriteria kevalidan didapatkan kriteria valid

\section{Saran}

Bahan ajar biologi umum berbasis kontekstual harus terus direvisi agar mendapatkan hasil yang lebih baik

\section{DAFTAR RUJUKAN}

Komalasari, Kokom. Pembelajaran Kontekstual Konsep dan Aplikasi. 2013. Bandung: Refika Aditama.

Kristiana, Indah, Arika. 2011. Pengembangan Perangkat Pembelajaran Berstandar NCTM pada Material Integral dengan Model 4-D.Tesis tidak diterbitkan. Malang: PPs UM.

Rusman. 2011. Model-Model Pembelajaran Mengembangkan Profesionalisme Guru. Jakarta: Raja Grafindo Persada.

Sugiyono. 2012. Metode Penelitian Pendidikan Pendekatan Kuantitatif, Kualitatif, dan $R \& D$. Bandung: Alfabeta.

Trianto. $2008 . \quad$ Mendesain Pembelajaran Kontekstual (Contextual Teaching and Learning) di Kelas. Jakarta: Cerdas Pustaka Publisher. 